\title{
MODEL PEMBELAJARAN CORE, SCRAMBLE, HASIL BELAJAR, DAN OPERASI HITUNG BENTUK ALJABAR
}

\author{
Nathalia Ilela, Christina Martha Laamena, Hanisa Tamalene \\ Universitas Pattimura, Ambon Jl. Ir. M. Putuhena, Poka, Tlk. Ambon, Kota Ambon, Maluku \\ E-mail: christinmath18@gmail.com
}

\begin{abstract}
Abstrak
Model pembelajaran memiliki peran penting terhadap hasil belajar siswa. Setiap model pembelajaran memiliki kontribusi yang berbeda-beda, sebagaimana model Scramble yang mampu membuat siswa berpikir cepat dan model CORE yang dapat melatih siswa berpikir kritis. Sehingga, penelitian ini bertujuan untuk membandingkan hasil belajar siswa yang diajarkan dengan kedua model tersebut, khususnya pada materi operasi hitung bentuk aljabar. Adapun metode penelitian yang digunakan adalah penelitian kuantitatif dengan posttest only group design yang tergolong dalam quasi eksperimental design. Populasi penelitian adalah 45 siswa kelas VII yang terbagi dalam 2 kelas. Instrumen tes yang digunakan berbentuk uraian sebanyak 5 soal yang digunakan untuk mengevaluasi hasil belajar siswa. Hasil penelitian yang dianalisis secara statistik dengan menggunakan uji-t menunjukkan bahwa terdapat perbedaan hasil belajar siswa antara kedua kelompok siswa. Selanjutnya uji lanjutan dengan Pairwise Comparisons menunjukkan bahwa siswa yang diajar dengan model pembelajaran Scramble mempunyai hasil belajar yang lebih baik dibandingkan siswa yang diajarkan dengan model pembelajaran CORE.
\end{abstract}

Kata Kunci: Hasil Belajar, Operasi Hitung Bentuk Aljabar, Model Pembelajaran CORE, Model Pembelajaran Scramble

\begin{abstract}
The learning model has an essential role in student learning outcomes. Each learning model has different contributions, such as the Scramble learning model, which can make students think quickly, and the CORE learning model can train students to think critically. Thus, this study aims to compare students' learning outcomes with the two models, especially in arithmetic operations in algebraic forms. The research method used is quantitative research with a posttest-only group design classified as a quasi-experimental design. The research population was forty-five seventhgrade students, which were divided into two categories. The test instrument used is a description of five questions used to evaluate student learning outcomes. The study results analyzed statistically using the t-test showed that there were differences in student learning outcomes between the two groups of students. Furthermore, the continued test using Pairwise Comparison showed that students taught with the Scramble learning model had better learning outcomes than students acquainted with the CORE learning model.
\end{abstract}

Keywords: Learning Outcomes, Arithmetic Operation of Algebraic Forms, CORE Learning Model, Scramble Learning Model

\section{PENDAHULUAN}

Matematika merupakan merupakan mata pelajaran yang bertujuan untuk mendidik anak agar berfikir logis, kritis, sistematis, memiliki sifat obyektif, jujur, disiplin dalam 
memecahkan permasalahan baik dalam bidang matematika, bidang lain, maupun dalam kehidupan sehari-hari (Bailang et al., 2017). Aktifitas manusia sehari-hari, tidak lepas dari peran serta matematika. Sebagai contoh, misalnya dalam transaksi jual beli di pasar, dalam aturan minum obat dari dokter, dalam mengukur bangunan, dan lain sebagainya. Itu artinya matematika merupakan hal yang kita butuhkan dalam kehidupan sehari-hari. Hal-hal inilah yang mendasari perlunya pembelajaran matematika di semua jenjang pendidikan dari SD hingga perguruan tinggi. Salah satu bidang matematika yang diajarkan di jenjang pendidikan adalah aljabar (Irsyad et al., 2019)

Permendikbud No. 21 Tahun 2016 menjelaskan bahwa aljabar mulai dipelajari siswa pada jenjang pendidikan SMP atau sederajat. Hal ini berarti, aljabar merupakan materi pelajaran harus dikuasai siswa SMP, terutama siswa kelas VII. Penguasaan konsep dasar aljabar di tingkat SMP akan memudahkan siswa untuk mempelajari aljabar lanjutan di tingkat SMA. Hal ini didukung dengan pendapat (Irsyad et al., 2019) yang menyatakan bahwa konsep matematika pada tingkat yang lebih tinggi akan mudah dipahami apabila konsep sebelumnya telah dipahami dengan baik. Ketika siswa telah mempelajari aljabar di SMP, maka siswa pasti akan menguasai aljabar dengan baik ketika berada pada jenjang pendidikan yang lebih tinggi (SMA).

Namun kenyataan di lapangan menunjukkan bahwa masih banyak siswa SMA yang mengalami kesulitan dalam bidang aljabar. Soedjadi (Sugiarti, 2017) mengatakan bahwa kesulitan yang dialami siswa akan memungkinkan terjadi kesalahan sewaktu menjawab soal tes. Kesalahan yang dilakukan siswa dalam menjawab masalah aljabar merupakan bukti adanya kesulitan yang dialami siswa pada materi tersebut. Irsyad, et al. (2019) mengungkapkan bahwa siswa sering melakukan kesalahan dalam menentukan hasil operasi hitung bentuk aljabar. Selain itu, Sukartiningsih (2020), menyatakan bahwa siswa mengalami kesulitan dalam operasi penjumlahan, pengurangan, perkalian, dan pembagian bentuk aljabar, serta menyelesaikan operasi pecahan pada bentuk aljabar. Beberapa faktor penyebabnya antara lain: cara belajar siswa yang cenderung menghafalkan materi sehingga tidak ada konsep yang jelas; siswa kebingungan dalam memahami konsep, karena prosedur pengerjaan yang rumit dan panjang; siswa kurang teliti, dan kurang cermat saat mengerjakan soal.

Lebih lanjut, hasil penelitian yang dilakukan oleh Limardani (2015), menunjukkan bahwa kesulitan yang dialami siswa dalam menyelesaikan soal operasi aljabar adalah 
adalah karena kesulitan dalam menuliskan pengertian suku, variabel, dan konstanta. Kesulitan lain yang dialami mereka yaitu kesulitan dalam membuat model matematika, kesulitan dalam memberikan contoh lain, dan kesulitan dalam menyatakan bentuk operasi aljabar ke bentuk operasi aljabar lainnya. Selain itu, siswa juga mengalami kesulitan dalam menyelesaikan persoalan yang berkaitan dengan operasi aljabar dan kesulitan dalam mengoperasikan berbagai permasalahan aljabar yang melibatkan syarat perlu dan syarat cukup.

Berkaitan dengan berbagai permasalahan tersebut, (Sugiarti, 2017) manyatakan bahwa faktor utama penyebab kesulitan siswa dalam menyelesaikan soal operasi bentuk aljabar adalah faktor eksternal yang berasal dari guru, terutama menyangkut penggunaan model pembelajaran yang bersesuaian dengan karakteristik materi yang ajarkan. Hal ini berarti guru perlu menerapkan metode pembelajaran yang tepat agar siswa tidak mengalami kesulitan dalam mempelajari materi bentuk aljabar. Terdapat berbagai model pembelajaran yang dapat digunakan guru, antara lain model pembelajaran CORE dan model Pembelajaran Scramble. Kedua model pembelajaran tersebut memiliki aktivitas pembelajaran yang berbeda, namun mempunyai tujuan yang sama, yaitu untuk meningkatkan pemahaman siswa terhadap materi pembelajaran.

Model CORE merupakan model pembelajaran yang menekankan siswa untuk berpikir, terutama untuk menghubungkan, mengorganisasikan, mendalami, mengelola dan mengembangkan informasi secara mandiri melalui proses diskusi kelompok. Menurut Shoimin (2014), model CORE memiliki empat komponen utama yakni: Connecting yang merupakan kegiatan mengkoneksikan informasi lama dan informasi baru dan antarkonsep; Organizing yangmerupakan kegiatan mengorganisasikan ide-ide untuk memahami materi; Reflecting yang merupakan kegiatan memikirkan kembali, mendalami, dan menggali informasi yang sudah didapat; dan Extending yang merupakan kegiatan untuk mengembangkan, memperluas, menggunakan, dan menemukan. Berkaitan dengan itu, maka model CORE cocok diterapkan pada materi operasi hitung bentuk aljabar. Hasil penelitian (Hariyanto, 2016), menyimpulkan bahwa penerapan model CORE dalam pembelajaran matematika dapat meningkatkan prestasi dan kemampuan komunikasi matematis siswa.

Model scramble merupakan salah satu tipe model kooperatif yang menyajikan sedikit permainan dalam kelompok yang dibentuk dan dapat membuat semua siswa yang 
tergabung dalam kelompoknya masing-masing lebih aktif menyelesaikan dan mencari jawaban atas pertanyaan maupun soal-soal yang disajikan (Sumartono \& Normalina, 2015). Berkaitan dengan itu maka model scramble cocok diterapkan pada materi operasi hitung bentuk aljabar karena walaupun dalam proses belajar siswa dituntut untuk saling bekerjasama, aktif, berpikir cepat dan tepat, siswa tidak akan jenuh dan bosan, karena model scramble ini disajikan dengan sedikit permainan berupa kartu. Hasil penelitian Bailang, et al. (2017) menyimpulkan bahwa penerapan model pembelajaran scramble meningkatkan hasil belajar siswa pada pembelajaran matematika.

Dengan demikian, kedua model tersebut merupakan model pembelajaran dengan aktivitas yang berbeda. Model scramble melatih siswa berpikir cepat sedangkan model pembelajaran CORE melatih daya pikir kritis siswa terhadap suatu masalah. Model CORE menuntut siswa untuk terus menerus berpikir dan memerlukan banyak waktu, sedangkan model scramble menuntut siswa untuk berpikir cepat dan melatih kedisiplinan siswa. Ditinjau dari pembelajaran kooperatif, model CORE mengarahkan siswa untuk dapat membangun pengetahuan secara mandiri melalui diskusi kelompok sedangkan pada model scramble, setiap anggota dalam kelompok dituntut untuk berkolaborasi, saling berkerjasama, saling menolong, aktif dan bertanggung jawab.

Kedua model ini penting untuk diterapkan dalam pembelajaran operasi hitung bentuk aljabar. Pembelajaran operasi hitung bentuk aljabar tidak saja membutuhkan kecepatan berpikir tetapi juga membutuhkan berpikir kritis. Selain akan meningkatkan hasil belajar siswa, kedua model juga dapat melatih siswa untuk berpikir cepat, berpikir kritis, disiplin, bekerja sama dan bertanggung jawab. Oleh karena itu, penelitian ini bertujuan untuk mengetahui ada tidaknya perbedaan hasil belajar antara kelompok siswa yang diajarkan dengan model pembelajaran CORE dan kelompok siswa yang diajarkan dengan model pembelajaran scramble pada materi operasi hitung bentuk aljabar di kelas VII SMP. Hasil penelitian diharapkan dapat merekomendasikan model pembelajaran yang lebih baik digunakan untuk meningkatkan kemampuan siswa dalam pembelajaran operasi hitung bentuk aljabar.

\section{METODE PENELITIAN}

Penelitian ini adalah penelitian kuantitatif dengan desain Posttest Only Group Design yang termasuk dalam Quasi Experimental Design (Desain Eksperimen Semu). 
Desain ini dipilih karena pemilihan sampel tidak dilakukan secara random tetapi menggunakan dua kelas yang telah ada. Kedua kelas diberikan perlakuan sehingga terdapat dua kelas eksperimen tanpa kelas kontrol. Desain penelitian dijelaskan pada Tabel 1 (Sukardi, 2011).

Tabel 1. Desain Penelitian Posttest Only Group Design

\begin{tabular}{ccc}
\hline Kelompok & Perlakuan & Post test \\
\hline Eksperimen 1 (E1) & P1 & $\mathrm{T}$ \\
Eksperimen 2 (E2) & P2 & $\mathrm{T}$ \\
\hline
\end{tabular}

Keterangan:

P1 : pembelajaran dengan menggunakan model CORE (E1)

P2 : pembelajaran dengan menggunakan model scramble (E2)

$\mathrm{T}$ : pemberian tes akhir untuk kelas ekperimen 1 dan kelas eksperimen 2

Populasi dalam penelitian ini adalah seluruh siswa kelas VII SMP Negeri 20 Ambon yang terdiri dari 2 kelas yaitu kelas VII-1 dan Kelas VII-2 dengan jumlah siswa 45 orang. Pengambilan sampel menggunakan 89eknik non probability sampling yaitu sampel jenuh. Sugiyono (2013) mengemukakan bahwa sampel jenuh dilakukan jika semua anggota populasi digunakan sebagai sampel. Sehingga sampel dalam penelitian ini adalah siswa kelas VII-1 dan Kelas VII-2 SMP Negeri 20 Ambon dengan jumlah siswa 45 orang. Kelas VII-1 sebagai kelas eksperimen 1, merupakan kelompok siswa yang diajarkan dengan model pembelajaran CORE, sedangkan kelas VII-2 sebagai kelas eksperimen 2, merupakan kelompok siswa yang diajarkan dengan model pembelajaran scramble.

Terdapat 2 variabel dalam penelitian ini yaitu hasil belajar siswa yang diajarkan dengan model pembelajaran CORE $\left(\mathrm{X}_{1}\right)$ dan hasil belajar siswa yang diajarkan dengan model pembelajaran scramble $\left(\mathrm{X}_{2}\right)$. Kedua variabel tersebut digunakan untuk membandingkan dua kelompok dari variabel prestasi belajar siswa. Dengan kata lain, nilai $\mathrm{X}_{1}$ dan $\mathrm{X}_{2}$ inilah yang akan diuji untuk mengetahui apakah terdapat perbedaan hasil belajar siswa antara kedua kelas eksperimen.

Perangkat pembelajaran yang disusun terdiri dari Rencana Pelaksanaan Pembelajaran (RPP), Lembar Kerja Siswa (LKS) dan bahan ajar serta kartu (soal \& jawaban). Rencana Pelaksanaan Pembelajaran (RPP) pada penelitian ini terdiri dari RPP untuk kelas eksperimen 1 dan RPP untuk kelas eksperimen 2, dengan masing-masing RPP 
disusun untuk 4 kali pertemuan. Selanjutnya pada pertemuan terakhir (pertemuan kelima), masing-masing kelas diberikan tes akhir. LKS hanya digunakan dalam proses belajar mengajar di kelas eksperimen 1. Pada proses pembelajaran di kelas eksperimen 2 digunakan bahan ajar (BA) dan Kartu (soal \& jawaban). Hal ini sesuai dengan aktifitas pembelajaran dari kedua model yang digunakan.

Instrumen yang digunakan untuk pengumpulan data yaitu dalam bentuk tes tertulis tentang operasi hitung bentuk aljabar. Data hasil penelitian yang diperoleh dianalisis dengan menggunakan Analisis Deskriptif dan Uji-t (uji beda rata-rata). Analisis deskriptif digunakan untuk mendeskripsikan hasil belajar siswa pada kedua kelas menggunakan Penilaian Acuan Patokan (PAP). Setelah itu dilakukan Uji-t (uji beda rata-rata) untuk melihat perbedaan antara kelas eksperimen 1 dan kelas eksperimen 2. Sebelum melakukan pengujian dengan uji-t terlebih dahulu dilakukan uji asumsi sebagai prasyarat analisis terhadap data nilai tes akhir siswa, yaitu dilakukan uji normalitas dan uji homogenitas pada kedua kelompok data. Data tersebut dianalisis menggunakan bantuan software SPSS (Statistical Product and Service Sulation) versi 25.0 for windows. Uji lanjutan untuk mengetahui model pembelajaran yang lebih baik dilakukan dengan menggunakan Pairwise Comparisons.

\section{HASIL DAN PEMBAHASAN}

Hasil

Hasil tes dikelompokkan berdasarkan penilaian acuan patokan (PAP) menurut Ratumanan dan Laurens (2011) dan disajikan pada Tabel 2.

Tabel 2. Distribusi Hasil Belajar Siswa Berdasarkan PAP

\begin{tabular}{lccccc}
\hline \multirow{2}{*}{ Kualifikasi } & Kelompok & \multicolumn{2}{c}{ Kelas E1 } & \multicolumn{2}{c}{ Kelas E2 } \\
\cline { 3 - 6 } & Nilai & Jumlah & Persentase & Jumlah & Persentase \\
\hline Sangat Baik & $90 \leq x$ & 0 & 0,00 & 0 & 0,00 \\
Baik & $75 \leq x<90$ & 8 & 34,78 & 13 & 59,09 \\
Cukup & $60 \leq x<75$ & 11 & 47,82 & 9 & 40,91 \\
Kurang & $40 \leq x<60$ & 2 & 8,70 & 0 & 0,00 \\
Sangat Kurang & $x<40$ & 2 & 8,70 & 0 & 0,00 \\
\hline
\end{tabular}


Pada Tabel 2, tampak bahwa tidak terdapat siswa yang memiliki kualifikasi sangat baik, untuk kelas eksperimen 1 maupun kelas ekperimen 2. Namun memiliki nilai siswa untuk kategori lainnya tidak terlalu berbeda antar dua kelompok eksperimen yang diuji dalam penelitian ini. Oleh karena itu untuk menentukan ada tidaknya perbedaan nilai ratarata prestasi siswa antar kedua kelas eksperimen tersebut, maka perlu melakukan pengujian menggunakan metode statistika.

Uji statistika dilakukan dengan didahului dengan melakukan asumsi meliputi uji normalitas dan uji homogenitas, dan kemudian dilanjutkan dengan uji hipotesis menggunakan uji t. Uji t dilakukan untuk mempelajari perbedaan prestasi belajar antar dua kelompok siswa yang menerima perlakuan yang berbeda. Prosedur pengujian untuk uji asumsi dan uji hipotesis berikut ini.

\section{Uji Normalitas Data}

Perumusan hipotesis pengujian normalitas untuk data post tes adalah:

$H_{0}$ : Data nilai post tes berdistribusi normal

$H_{1}$ : Data nilai post tes tidak berdistribusi normal

Dengan menggunakan taraf signifikansi $5 \%(\alpha=0,05)$ maka kriteria pengujiannya adalah:

a) Jika nilai signifikasi (Sig) $\geq 0,05$ maka $H_{0}$ diterima

b) Jika nilai signifikasi (Sig) $<0,05$ maka $H_{0}$ ditolak

Dari hasil perhitungan dengan menggunakan SPSS 25.0 for Windows dilakukan uji normalitas menggunakan uji Kolmogorov-Smirnov dengan taraf signifikansi 5\% diperoleh hasil yang disajikan pada Tabel 3.

Tabel 3. Hasil Uji Normalitas Data

\begin{tabular}{lcccccc}
\hline & \multicolumn{3}{c}{ Kolmogorov-Smirnov $^{\text {a }}$} & \multicolumn{3}{c}{ Shapiro-Wilk } \\
\cline { 2 - 7 } & Statistic & df & Sig. & Statistic & df & Sig. \\
\hline $\begin{array}{l}\text { Hasil belajar siswa } \\
\text { kelas eksperimen1 }\end{array}$ & .183 & 22 & .054 & .875 & 22 & .010 \\
$\begin{array}{l}\text { Hasil belajar siswa } \\
\text { kelas eksperimen2 }\end{array}$ & .172 & 22 & .088 & .911 & 22 & .049 \\
\hline
\end{tabular}

a Liliefors Significance Correction 
Berdasarkan Tabel 3, tampak bahwa pada kelas eksperimen 1 nilai Sig. lebih besar dari $\alpha=0.05$, yaitu 0.054 . Hal yang sama juga terlihat pada kelas eksperimen 2, nilai Sig lebih besar dari $\alpha=0.05$, yaitu 0.088 . Hal ini menunjukkan bahwa $H_{1}$ ditolak atau $H_{0}$ diterima. Dengan demikian dapat disimpulkan bahwa data penelitian merupakan sampel dari populasi yang berdistribusi normal.

\section{Uji Homogenitas Data}

Perumusan hipotesis pengujian data homogen untuk data post tes adalah:

$H_{0}$ : sampel memiliki varians yang homogen

$H_{1}$ : sampel memiliki varians yang tidak homogen

Dengan menggunakan taraf signifikansi 5\% $(\alpha=0,05)$ maka kriteria pengujiannya adalah:

a) Jika nilai signifikansi (Sig.) $\geq 0,05$ maka $H_{0}$ diterima

b) Jika nilai signifikansi (Sig.) $<0,05$ maka $H_{0}$ ditolak

Berdasarkan hasil uji Levene, dengan menggunakan software SPSS 25.0 for Windows, maka diperoleh hasil pengujian sebagaimana yang disajikan pada Tabel 4.

Tabel 4. Hasil Uji Homogenitas/Keragaman Data

\begin{tabular}{llrrrr}
\hline & Levene Statistic & df1 & df2 & \multicolumn{2}{c}{ Sig. } \\
\hline Hasil belajar & Based on mean & 1.588 & 1 & 43 & .214 \\
siswa kelas & Based on Median & 1.201 & 1 & 43 & .279 \\
eksperimen 1 & Based on Median and & 1.201 & 1 & 30.674 & .282 \\
dan eksperimen & with adjusted df & & & & \\
2 & Based on trimmed mean & 1.201 & 1 & 43 & .277 \\
\hline
\end{tabular}

Pada Tabel 4, terlihat bahwa nilai Sig untuk hasil belajar siswa kelas ekperimen 1 dan kelas eksperimen 2, untuk nilai rata-rata (based on mean), adalah lebih besar dari $\alpha=0,05$, yaitu 0.214 . Hal ini berarti bahwa $H_{0}$ diterima, sehingga dapat disimpulkan bahwa keragaman data untuk kedua kelas eksperimen tersebut adalah homogen. Dengan demikian analisis data menggunakan uji $t$ dapat dilakukan untuk menguji hipotesis penelitian. 


\section{Uji Hipotesis}

Pengujian hipotesis dilakukan untuk mengetahui ada tidaknya perbedaan antara hasil belajar siswa yang diajarkan dengan menggunakan model pembelajaran CORE dan hasil belajar siswa yang diajarkan dengan menggunakan model pembelajaran scramble. Hipotesis yang diuji dalam penelitian ini adalah:

$H_{0}$ : sampel memiliki varians yang homogen $H_{1}$ : sampel memiliki varians yang tidak homogen Dengan menggunakan taraf signifikansi 5\% $(\alpha=0,05)$ maka kriteria pengujiannya adalah:

a) Jika nilai signifikansi Sig.(2-tailed) $\geq 0,05$ maka $H_{0}$ diterima

b) Jika nilai signifikansi Sig.(2-tailed) $<0,05$ maka $H_{1}$ diterima

Berdasarkan hasil t-test dengan menggunakan software SPSS 25.0 for Windows, diperoleh hasil sebagaimana disajikan pada Tabel 5.

Tabel 5. Hasil Uji Perbedaan antara Kelompok Eksperimen

\begin{tabular}{|c|c|c|c|c|c|c|}
\hline & & \multicolumn{5}{|c|}{ t-test for Equality of Means } \\
\hline & & $\mathbf{t}$ & df & $\begin{array}{c}\text { Sig. } \\
\text { (2-tailed) }\end{array}$ & $\begin{array}{c}\text { Mean } \\
\text { difference }\end{array}$ & $\begin{array}{l}\text { Std. Error } \\
\text { Difference }\end{array}$ \\
\hline \multirow{4}{*}{$\begin{array}{l}\text { Hasil belajar } \\
\text { siswa kelas } \\
\text { eksperimen } 1 \& \\
\text { eksperimen2 }\end{array}$} & Equal variance & & & & & \\
\hline & assumed & -2.650 & 43 & .011 & -8.62990 & 3.25634 \\
\hline & Equal variance & & & & & \\
\hline & not assumed & -2.677 & 36.977 & .011 & -8.62990 & 3.25634 \\
\hline
\end{tabular}

Berdasarkan Tabel 5, tampak bahwa diperoleh nilai sig. (2-tailed), pada keragaman data yang diasumsi sama (equal variance assumed), adalah lebih kecil dari nilai $\alpha=$ 0,05, yaitu sebesar 0,011. Hal ini menunjukkan bahwa taraf signifikansi $\alpha=5 \%$, hipotesis $\mathrm{H}_{0}$ ditolak. Dengan demikian dapat disimpulkan bahwa terdapat perbedaan hasil belajar antara kelompok siswa yang diajarkan dengan model pembelajaran CORE dan kelompok siswa yang diajarkan dengan model pembelajaran Scramble.

Lebih lanjut, dilakukan perbandingan berpasangan (pairwise comparisons), menggunakan software SPSS 25.0 for Windows, untuk mengetahui kelompok siswa mana yang mempunyai hasil belajar yang lebih baik dibandingkan dengan kelompok siswa lainnya. Hasil pengujian berupa selang kepercayaan 95\% untuk perbedaan hasil belajar 
antara kedua kelompok siswa, disajikan pada Tabel 6.

Tabel 6. Selang Kepercayaan 95\% Perbedaan Kedua Kelompok Eksperimen

\begin{tabular}{lcrc}
\hline & \multirow{2}{*}{ Model Pembelajaran } & \multicolumn{2}{c}{$\mathbf{9 5 \%}$ Confidence Interval for Difference } \\
\cline { 3 - 4 } & Scramble & $-15,197$ & Lpwer Bound \\
\hline CORE & CORE & 2,063 & $-2,063$ \\
Scramble & Cowe & 15,197 \\
\hline
\end{tabular}

Berdasarkan Tabel 6, tampak bahwa selang kepercayaan (confidence interval) 95\% untuk rata-rata selisih antara hasil belajar kelompok siswa yang diajarkan dengan model CORE dan yang diajarkan dengan model Scramble memiliki nilai negatif (baik untuk nilai terendah maupun nilai tertinggi). Hal ini menunjukkan bahwa hasil belajar kelompok siswa yang diajarkan dengan model CORE lebih rendah dari hasil belajar kelompok siswa yang diajarkan dengan model Scramble. Hasil yang tidak berbeda bila perbandingkan dilakukan antara kelompok siswa yang diajarkan dengan model Scramble dengan kelompok siswa yang diajarkan dengan model CORE, yaitu memiliki nilai positif. Dengan demikian dapat disimpulkan bahwa hasil belajar siswa yang diajarkan dengan model pembelajaran scramble lebih baik dibandingkan hasil belajar kelompok siswa yang diajarkan dengan model pembelajaran CORE.

\section{Pembahasan}

Berdasarkan hasil analisis data diperoleh bahwa terdapat perbedaan rata-rata hasil belajar siswa yang diajarkan dengan menggunakan model pembelajaran CORE dan model pembelajaran scramble pada materi operasi hitung bentuk aljabar. Kelas yang diajarkan dengan menggunakan model pembelajaran scramble menunjukkan hasil belajar yang lebih baik dibandingkan dengan kelas yang diajarkan menggunakan model pembelajaran CORE. Hal ini nampak pada perbedaan nilai rata-rata hasil belajar siswa yakni untuk kelas yang diajarkan dengan model pembelajaran scramble memperoleh nilai rata-rata 76,25 lebih tinggi dari kelas yang diajarkan dengan model pembelajaran CORE yang hanya memperoleh rata-rata 67,62 .

Perbedaan ini disebabkan beberapa hal, antara lain tahapan pembelajaran yang berbeda, karakteristik model pembelajaran yang berbeda dan terdapat permainan pada model pembelajaran scramble. Selain itu kecocokan model pembelajaran dan materi juga 
merupakan faktor yang menyebabkan terjadinya perbedaan hasil belajar antara kedua kelas.

Pada pembelajaran menggunakan model CORE siswa mengoneksikan informasi lama dan informasi baru, menghubungkan antarkonsep kemudian mengorganisasikan ide-ide untuk memahami materi. Setelah itu siswa memikirkan kembali, mendalami, dan menggali informasi yang sudah diperoleh serta mengembangkan, memperluas, menggunakannya. Pada bagian ini siswa sering mengalami kesulitan karena kemampuan koneksi matematika yang masih rendah. Menurut Aliyah, Yuhana dan Santosa (2019) siswa masih membutuhkan waktu yang lama dan mengalami berbagai kendala dalam mengoneksikan apa yang telah dan sedang dipelajari. Putri dan Riwayati (2017) menjelaskan bahwa lemahnya kemampuan koneksi siswa terlihat dari ketidakmampuan siswa dalam menghubungkan konsep-konsep atau materi yang telah di pelajari, dan membuat mereka sulit untuk mengerjakan soal yang diberikan oleh guru.

Siswa pada kelas dengan pembelajaran model CORE tidak diberikan bahan ajar tetapi hanya LKS dan mereka diminta untuk mengonstruksi sendiri konsep operasi bentuk aljabar. Hal ini juga menjadi penyebab hasil belajar siswa lebih rendah dibandingkan dengan kelas Scramble. Subanji (2015) menjelaskan bahwa kebanyakan siswa hanya sekedar meniru prosedur yang sudah dilakukan oleh guru. Bahkan seringkali siswa tidak tahu mengapa harus menggunakan prosedur seperti itu. Hal yang penting bagi siswa adalah menggunakan prosedur yang dicontohkan oleh guru dan memperoleh jawaban yang sesuai dengan kehendak guru. Akibatnya ketika siswa diminta mengonstruksi pengetahuan atau konsep mereka sendiri tentang operasi bentuk aljabar, hasil yang diharapkan tidak akan maksimal.

Pada pembelajaran dengan model scramble siswa menggunakan bahan ajar yang menjadi kekuatan siswa dalam pembelajaran. Putri (2016) menjelaskan pentingnya bahan ajar yakni sebagai pusat pembelajaran dan berfungsi sebagai alat pembelajaran yang strategis bagi guru dan peserta didik, serta menciptakan kelangsungan pembelajaran dengan kegiatan-kegiatan inovatif dan penuh daya tarik. Hasil penelitian Maskur, Permatasari dan Rakhmawati (2020) menyatakan bahwa bahan ajar juga dibutuhkan oleh guru untuk pendamping peserta didik dalam belajar.

Media kartu pada model pembelajaran scramble juga menjadi salah satu penyebab terjadinya perbedaan hasil belajar antara kedua kelas. Laurens dan Laamena (2019) 
mengemukakan bahwa media adalah kunci penting dalam belajar matematika, khususnya pada siswa pada pendidikan dasar. Hal ini disebabkan karena matematika yang abstrak dan sukar dipahami oleh siswa yang masih berada pada tahap berpikir konkrit. Selain itu permainan kartu juga menyenangkan siswa. Dalam kegiatan-kegiatan yang menyenangkan, siswa merasa lebih termotivasi untuk belajar dan berpikir. Hal ini bersesuaian dengan hasil penelitian Souhoka, Ayal dan Laamena (2019) yang menyatakan bahwa dalam pelaksanaannya didukung dengan keaktifan siswa bergerak mencari pasangan dengan kartu yang sesuai dengan jawaban atau pertanyaan dalam kartu.

Pada proses pembelajaran menggunakan model scramble, siswa melakukan aktivitas belajar melalui diskusi dalam kelompok. Dalam proses diskusi siswa berbagi tugas, sangat aktif, dan bekerjasama dalam menyelesaikan soal yang ada pada kartu soal. Selain itu suasana belajar dalam proses diskusi sangat menyenangkan karena siswa belajar sambil bermain sehingga tidak timbul rasa jenuh. Hal ini sesuai dengan pendapat Sumartono \& Normalina (2015), yang menyatakan bahwa model scramble menyajikan sedikit permainan dalam kelompok yang dibentuk dan dapat membuat semua siswa yang bergabung dalam kelompoknya masing-masing lebih aktif menyelesaikan dan mencari jawaban atas pertanyaan maupun soal-soal yang disajikan. Selama proses diskusi berlangsung, guru berkeliling melakukan bimbingan-bimbingan supaya tercipta pembelajaran yang efektif. Hal ini sesuai dengan pendapat yang dikemukakan oleh Prawoto (2012) bahwa pembelajaran yang efektif menghendaki guru memfasilitasi siswa belajar dengan diskusi agar siswa bisa belajar kerjasama dan bisa belajar aktif untuk melatih keberanian dan kepercayaan diri siswa dalam proses pembelajaran di kelas. Setelah proses diskusi selesai, siswa mempresentasikan hasil jawaban yang sudah dikerjakan dalam kelompoknya. Setelah itu, siswa yang lain menanggapi dan mengevaluasi tanggapan siswa lain dan hasil belajar setiap kelompok. Guru memberikan poin bagi jawaban yang benar dan memberikan motivasi dari jawaban yang salah. Selanjutnya, pada akhir pembelajaran guru melakukan pembimbingan untuk menyimpulkan materi yang telah dipelajari.

Hasil belajar menggunakan model pembelajaran scramble lebih baik daripada model pembelajaran CORE disebabkan karena terdapat beberapa kelebihan dari model scramble yang tidak dimiliki oleh model pembelajaran CORE yakni untuk model scramble siswa dilatih untuk berpikir cepat dan tepat. Hal ini sesuai dengan pendapat 
Taylor (Huda, 2013), yang menyatakan bahwa model scramble merupakan salah satu model pembelajaran yang dapat meningkatkan konsentrasi dan kecepatan berpikir siswa. Sedangkan untuk model CORE siswa membutuhkan banyak waktu untuk menyelesaikan masalah yang diberikan, hal ini diungkapkan Khafidhoh (Indarwati et al., 2018), bahwa salah satu kekurangan model CORE adalah membutuhkan banyak waktu.

Penerapan model scramble dalam pembelajaran memberikan banyak manfaat positif bagi siswa antara lain: 1) membina karakter tanggung jawab dan disiplin siswa. Hal ini dukung oleh penelitian (Pasani et al., 2018), bahwa penerapan model kooperatif tipe scramble dalam pembelajaran matematika dapat membina karakter tanggung jawab dan disiplin siswa. 2) Berpikir kritis. Hal ini didukung oleh penelitian (Manalu \& Siregar, 2019), bahwa model pembelajaran scramble efektif digunakan pada kemampuan berpikir kritis siswa. 3) Meningkatkan kemampuan pemecahan masalah. Hal ini didukung oleh penelitian (Fitrianti et al., 2019), bahwa model pembelajaran kooperatif tipe scramble dengan media Question Card dapat meningkatkan kemampuan pemecahan masalah siswa kelas.

Faktor lain yang turut menjadi penyebab hasil belajar kelas scramble lebih baik adalah argumentasi yang dibangun siswa selama proses diskusi. Argumen-argumen siswa selama diskusi tersimpan lama dalam memori siswa dibandingkan ketika mereka hanya mendengar apa yang disampaikan guru atau teman. Akibatnya ketika mereka dihadapkan dengan masalah dalam hal ini tes akhir mereka mudah menyelesaikannya. Laamena (2019) menjelaskan bahwa argumentasi dapat meningkatkan pengetahuan siswa, khusus pengetahuan konseptual serta memberikan kesempatan kepada siswa untuk berkembang ke level literasi yang lebih tinggi.

\section{KESIMPULAN}

Hasil belajar siswa yang diajarkan materi operasi hitung bentuk aljabar dengan menggunakan model pembelajaran scramble lebih baik dibandingkan siswa yang diajarkan dengan menggunakan model pembelajaran CORE (Connecting, Organizing, Reflecting, and Extending). Pembelajaran operasi bentuk aljabar lebih cocok menggunakan model pembelajaran scramble karena materi yang tidak membutuhkan penaralan mendalam tetapi lebih menekankan keterampilan aljabar sehingga lebih membutuhkan kecepatan dibandingkan berpikir kritis. Model pembelajaran scramble 
juga memberikan kesempatan kepada siswa untuk disiplin, bertanggungjawab dan disiplin serta meningkatkan kemampuan pemecahan masalah.

\section{DAFTAR PUSTAKA}

Aliyah, I. M., Yuhana, Y., \& Santosa, C. A. H. F. (2019). Kemampuan Koneksi Matematis Siswa Ditinjau dari Kemampuan Awal dan Gender. Jurnal Didaktik Matematika, 6(2), 161-178.

Bailang, I., Emor, J., \& Wenas, J. (2017). Penerapan Model Pembelajaran Kooperatif Tipe Scramble Terhadap Hasil Belajar Matematika Pada Materi Persamaan Linear Satu Variabel. Jurnal Sains, Matematika, \& Edukasi FMIPA Unima, 5(2), 132-137.

Fitrianti, A., Abidin, Z., \& Alifiani. (2019). Penerapan Model Pembelajaran Kooperatif Tipe Scramble dengan Media Question Card untuk Meningkatkan Kemampuan Pemecahan Masalah Siswa Pada Materi Statistika Kelas VIII-A SMP Wahid Hasyim Malang. Jurnal Penelitian, Pendidikan dan Pembelajaran, 14(6), 87-92.

Hariyanto. (2016). Penerapan Model Core dalam Pembelajaran Matematika untuk Meningkatkan Kemampuan Komunikasi Matematik Siswa. Jurnal Gammath, 1(2), $33-40$.

Huda, M. (2013). Cooperative Learning Metode, Teknik, Struktur, dan Model Penerapan. Yogyakarta: Pustaka Pelajar.

Indarwati, C., Kriswandani, \& Yuniana, T. (2018). Perbedaan Kemampuan Pemecahan Masalah Matematika Bagi Siswa yang Diberi Model PBI dan Core bagi Siswa Kelas VII SMP Negeri 1 Ampel Kabupaten Boyolali. Jurnal Mitra Pendidikan, 2(1), 11-22.

Irsyad, Y. M., Sulastri, \& Hidayah, I. (2019). Meningkatkan Pemahaman Konsep Matematis Siswa Kelas VII G melalui Model Discovery Learning Berbantuan Question Cards di SMPN 22 Semarang. PRISMA, Prosiding Seminar Nasional Matematika, 2, 466-472.

Laamena, C. M. (2019). Strategi Scaffolding berdasarkan Gaya Belajar dan Argumentasi Siswa: Studi Kasus pada Pembelajaran Pola Bilangan. Barekeng: Jurnal Ilmu Matematika dan Terapan, 13(2), 85-92.

Laurens, T., \& Laamena, C. M. (2020). Development of Mathematical Learning Devices Based on Multimedia on Circle Materials of Grade Eighth of Junior High School. IOP Conf. Series: Journal of Physics: Conf. Series, 1470(1), 012088.

Manalu, W. R., \& Siregar, E. Y. (2019). Efektivitas Model Pembelajarn Scramble terhadap Kemampuan Berpikir Kritis Matematis Siswa di SMP Negeri 2 Pandan. Jurnal MathEdu, 2(2), 93-98.

Maskur, R. Permatasari, D. dan Rakhmawati, R.M. (2020). Pengembangan Bahan Ajar 
Matematika Berbasis Rhythm Reading Vocal pada Materi Konsep Pecahan Kelas VII SMP. Kreano: Jurnal Matematika Kreatif-Inovatif, 11(1), 78-87.

Pasani, C. F., Kusumawati, E., \& Imanisa, D. (2018). Penerapan Pembelajaran Kooperatif Tipe Scramble dalam Pembelajaran Matematika untuk Membina Karakter Tanggung Jawab dan Disiplin Siswa. Jurnal Pendidikan Matematika, 6(2), 178188.

Prawoto, A. (2012). Pembelajaran dengan Pendekatan Based Brain Learning untuk Meningkatkan Hasil Belajar Matematika. Tesis. Bandung: Pascasarjana Universitas Pendidikan Indonesia.

Purwanto. (2009). Prinsip-Prinsip Dan Teknik Evaluasi Pengajaran. Bandung: Remaja Rosdakarya

Putri, J. W. \& Riwayati, S. (2017). Kemampuan Koneksi Matematis Siswa pada Model Pembelajaran Conneted Mathematics Project (CMP). Fibonacci: Jurnal Pendidikan Matematika dan Matematika, 3(2), 161-168.

Putri, F. M. (2016). Pengembangan Bahan Ajar Matematika Dasar Layanan Jurusan Non Eksak. FIBONACCI: Jurnal Pendidikan Matematika dan Matematika, 2(1), 44-52

Ratumanan, T. G. \& Laurens, T. (2011). Penilaian Hasil Belajar pada Tingkat Satuan Pendidikan. Surabaya: Unessa University Press.

Shoimin, A. (2014). Model Pembelajaran Inovatif dalam Kurikulum 2013. Yogyakarta: Ar-Ruzz Media.

Souhoka, F. P., Ayal, C. S., \& Laamena, C. M. (2019). Perbedaan Hasil Belajar Siswa Menggunakan Model Pembelajaran Kooperatif Tipe Make a Match dan Model Pembelajaran Konvensional Pada Materi Statistika. Prosiding Seminar Nasional Pendidikan Matematika Universitas Pattimura.

Subanji. (2015). Teori Kesalahan Konstruksi Konsep dan Pemecahan Masalah. Matematika. Malang: UM Press

Sugiarti, L. (2017). Kesulitan Siswa dalam Menyelesaikan Soal Operasi Bentuk Aljabar. Prosiding Seminar Nasional Etnomatnesia, 323-330.

Sukardi. (2011). Metodologi Penelitian Pendidikan. Jakarta: Bumi Aksara

Sukartiningsih. (2020). Peningkatan Keaktifan dan Hasil Belajar Matematika Materi Operasi Bentuk Aljabar Melalui Model Pembelajaran Think Pair Share dengan Love Notes Peserta Didik Kelas VII. Kreatif, Jurnal Kependidikan Dasar, 10(2), 170-181.

Sumartono \& Normalina. (2015). Motivasi dan Hasil Belajar Siswa dalam Pembelajaran Matematika dengan Menggunakan Model Pembelajaran Kooperatif Tipe Scramble di SMP. Jurnal Pendidikan Matematika, 3(1), 84-91.

Yudhawati, R., \& Haryanto, D. (2011). Teori-teori Dasar Psikologi Pendidikan. Jakarta: 
Journal of Honai Math, Vol. 4, No. 1, pp. 85-100, April 2021

Ilela, Laamena, \& Tamalene, Model Pembelajaran Core, Scramble, Hasil Belajar, ...

Prestasi Pustakaraya. 